\title{
Use of a pilot scale heat exchanger-cooling tower system for the evaluation of mineral scale inhibitors
}

\author{
E. Antonogiannakis, E. Tzagkaraki and K. D. Demadis* \\ Crystal Engineering, Growth and Design Laboratory, Department of Chemistry, \\ University of Crete, Voutes Campus, Crete, GR-71003, Greece \\ *Corresponding Author.E-mail: demadis@chemistry.uoc.gr
}

\begin{abstract}
A pilot heat exchanger-cooling tower prototype was constructed and used for the evaluation of scale inhibitors in the inhibition of calcium carbonate $\left(\mathrm{CaCO}_{3}\right)$ precipitation and deposition. The chemical additives that were used as inhibitors were 2phosphonobutane-1,2,4-tricarboxylic acid (PBTC, Dequest 7000), bis(hexamethylene triaminepenta (methylenephosphonic acid)) (BHPMP, Dequest 2090) and two carboxylatebased polymers of the carboxymethyl inulin family (Dequest PB 11615 and PB 11620). The carboxylate-based polymers are "green" additives since they are environmentallyfriendly, non toxic and biodegradable. Experiments were carried out in the absence of inhibitors (control) using local city water, and then in the presence of inhibitors. The inhibitors tested showed variable inhibitory activity in $\mathrm{CaCO}_{3}$ formation and deposition onto the heat exchanger. This conclusion was based on macroscopic observation $\left(\mathrm{CaCO}_{3}\right.$ fouling) and on soluble $\mathrm{Ca}^{2+}$ measurements. Finally, the role of temperature of the heat exchanger, the heating time and the water flow within the unit were very important factors for $\mathrm{CaCO}_{3}$ fouling on the heated surface, considering the $\mathrm{CaCO}_{3}$ inverse solubility features.
\end{abstract}

Key words: scale, deposit, scale inhibitors, phosphonates, carboxymethyl inulin, green chemistry, calcium carbonate, crystal modifier.

Received: 03.07.2013.

doi: $\underline{10.17675 / 2305-6894-2013-2-4-255-268}$

\section{Introduction}

Industrial water systems face several challenges related to formation of sparingly soluble electrolytes [1]. Cooling water systems, in particular, may suffer from a multitude of problems. Utility plants and manufacturing facilities use "hot" processes for their operations. These processes have to be cooled. Water is the universal cooling medium because it is cost effective and has a high heat capacity [2]. After the cooling water comes in contact with the "hot" process, it needs to be re-cooled for reuse. This cooling is achieved by partial water evaporation. The end result of this process is the concentration of all soluble species found in the recirculating water until they reach a critical point of "scaling", leading to precipitation, and ultimately deposition of mineral salts. The identity of the salt to be deposited depends on water chemistry, and its solubility product, $K_{\mathrm{sp}}$. The species usually associated with these deposits are calcium carbonate, calcium phosphate(s), 
silica/metal silicates etc. Figure 1 shows representative examples of scale deposits onto industrial heat exchangers and tubes.
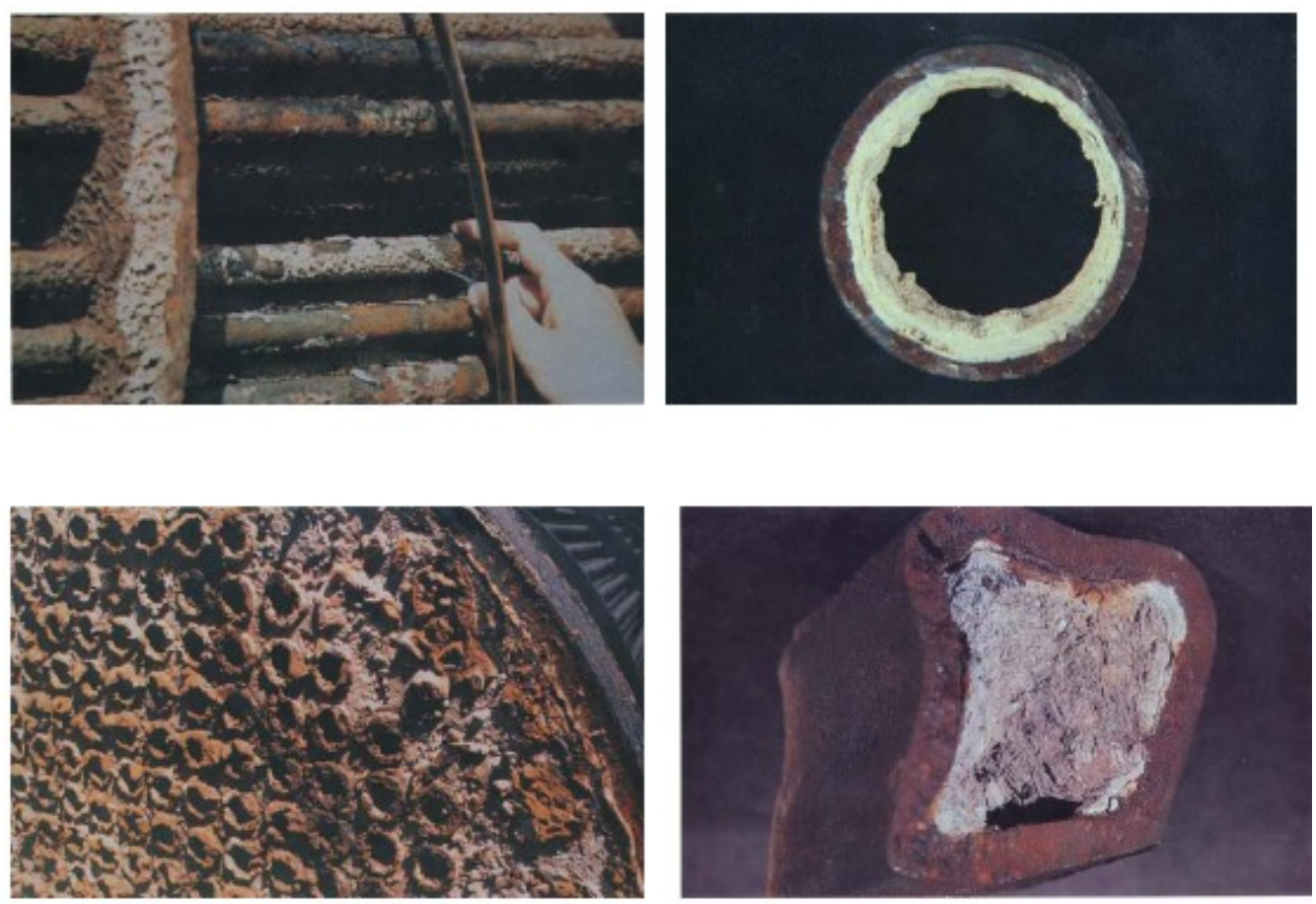

Figure 1. Scaled heat exchanger tube bundles (left images) and tubing (right images).

Such undesirable deposition issues can be avoided with the careful application of chemical water treatment techniques [3]. Prevention of scale formation is greatly preferred by industrial water users to the more costly (and often potentially hazardous) chemical cleaning [4] of the adhered scale, in the aftermath of a scaling event. Classic examples of scales that require laborious (mechanical) and potentially dangerous (hydrofluoric acid) cleaning are silica and silicate salts [5]. Prevention of scale deposit formation can also benefit the water operator by eliminating (or at least by minimizing) unexpected production shut-downs and by offering substantial savings through water conservation (especially in areas with high water costs).

Phosphorous compounds, usually referred to as organic phosphates or phosphonates, are an integral part of a water treatment program [6]. They function as scale inhibitors by adsorbing onto crystal surfaces of insoluble salts and prevent further crystal growth [7]. Polymers are also used as scale inhibitors. They often possess acidic sites, most commonly carboxylic acid residues [8].

Phosphonates usually contain multiple phosphonate groups $\left(\mathrm{R}-\mathrm{PO}_{3} \mathrm{H}_{2}, \mathrm{R}=\right.$ organic chain) most commonly found in their deprotonated form, due to the particular $\mathrm{pH}$ range of operation (virtually all cooling water programs operate at $\mathrm{pH}$ 's in the range 7.0 to 9.8). These additives perform scale inhibition in "ppm" quantities and usually work synergistically with dispersant polymers [9]. 


\section{Experimental Section}

Water chemistry. For the scaling experiments local city water was used that contained $70 \mathrm{ppm} \mathrm{Ca}$ and $150 \mathrm{ppm} \mathrm{HCO}_{3}^{-}$, according to chemical analyses provided by the Heraklion Water and Sewage Authority.

Materials. The inhibitors used were 2-phosphonobutane-1,2,4-tricarboxylic acid (PBTC) with the commercial name Dequest 7000, Bis-Hexamethylenetriaminepentakis(methylenephosphonic acid) (BHPMP) with the commercial name Dequest 2090, and Carboxymethyl inulin polymers (CMI), with the commercial names Dequest PB11615 and Dequest PB-11620. The last two digits denote the degree of substitution (DS) per monomer ring. DS $=15$ means that there are 1.5 carboxylic acid groups (on average) per fructose unit, whereas DS $=20$ means that there are 2.0 carboxylic acid groups (on average) per fructose unit. The CMI biopolymers have an average molecular weight of $\sim 2500 \mathrm{Da}$. Schematic structures of the inhibitors are shown in Figure 2.

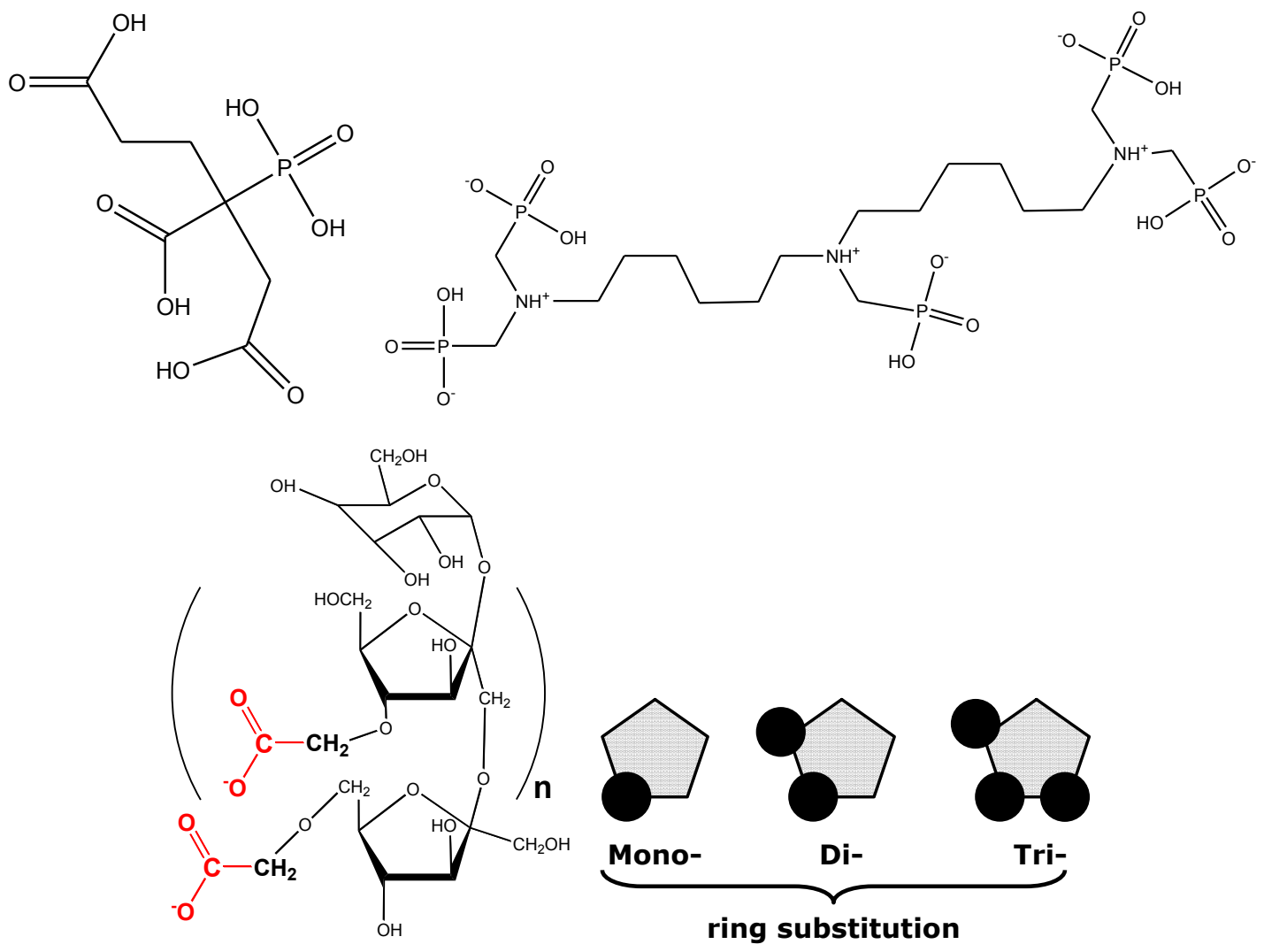

Figure 2. Schematic structures of the inhibitors used in this study: PBTC upper left, BHPMP upper right, CMI polymers lower left. The multiple fructose ring substitution is shown at the lower right image.

CMI is produced from a chemical reaction with a biopolymer and select reagents [10]. This biopolymer, inulin [11], is extracted from the roots of the chicory plant (dry matter content: $20-25 \%$, inulin content: $14.9-18.3 \%$ ). Inulin is a polydisperse polysaccharide 
consisting mainly, if not exclusively, of $\beta(2 \rightarrow 1)$ fructosyl fructose units with normally, but not necessarily, one glucopyranose unit at the reducing end. It is also known that the fructose molecules are all present in the furanose form. Inulin is used as dietary fiber, fat substitute, sweetener (fructose syrups). Carboxymethylinulin (CMI) has been investigated in a series of acute toxicity (oral rat, $>2000 \mathrm{mg} / \mathrm{kg} \mathrm{B}$.W.), sub-acute toxicity (28 days, rat $1000 \mathrm{mg} / \mathrm{kg} \mathrm{B.W.),} \mathrm{mutagenicity} \mathrm{(Ames} \mathrm{Test,} \mathrm{in} \mathrm{vitro} \mathrm{cytogenetics,} \mathrm{no} \mathrm{effect)} \mathrm{and} \mathrm{dermal}$ sensitization studies (guinea pigs, no effect) to evaluate its toxicological profile [12]. All studies followed accepted testing guidelines as recommended by international regulatory agencies (OECD, EEC and US EPA). No significant toxicological findings were evident. Results of the present toxicity studies with CMI, all conforming to internationally-accepted testing standards, show that the toxicological profile of CMI is consistent with other polycarboxylates used in foods. Among other attractive attributes of CMI, its inherent biodegradability and non-toxicity are most prominent. Data that support these conclusions include: toxicity (ppm) $\mathrm{EC}_{10}>10000$, bacteria (ppm) $\mathrm{EC}_{0}=2000$, Daphnia (ppm) $\mathrm{EC}_{50(24 \mathrm{~h})}$ $=5500$, fish $(\mathrm{ppm}) \mathrm{LC}_{0}>10000$ [13]. These results should be contrasted to those obtained for a polyacrylate polymer $(\mathrm{M} . \mathrm{W} .=1500)$ commonly used as precipitation inhibitor [14]: toxicity (ppm) $\mathrm{EC}_{10}=180$, bacteria $(\mathrm{ppm}) \mathrm{EC}_{0}=200$, Daphnia $(\mathrm{ppm}) \mathrm{EC}_{50(24 \mathrm{~h})}=240$, fish (ppm) $\mathrm{LC}_{0}=200$.

Dynamic precipitation/deposition experiments. In a previous paper [15] we described the design and construction of a pilot heat exchanger/cooling tower prototype. The system integrates a heat exchanger that can be heated to the desired temperature. Cooling water, by means of a recirculating pump, flows over the heat exchanger, thus performing the cooling action. Then, the "hot water" flows over the cooling tower and, through a sprayer, into the tower fill, where, by means of partial evaporation, is re-cooled. A topside fan assists in the water re-cooling process. The "cooled" water is collected in the tower basin, where it goes on to continue the cooling action onto the heat exchanger.

The dynamic experiments were run for 6-8 hours, depending on the particular experiment. Samples of the recirculating water were withdrawn, placed into plastic vials and "quenched" with a few drops of concentrated $\mathrm{HCl}$ to stop further precipitation. They were then analyzed with Atomic Absorption for calcium.

Control experiments were run first. Then, under identical conditions the same experiments were run in the presence of inhibitors. The inhibitor dosage used was $50 \mathrm{ppm}$, and the inhibitor was added a few minutes after the start of each experiment in a high flow area. The $\mathrm{pH}$ of the recirculating water was not adjusted, but was allowed to acquire the equilibrium value, $\sim 8.8$.

\section{Results and Discussion}

\section{$\mathrm{CaCO}_{3}$ precipitation and deposition in the absence of inhibitors (control)}

During the control experiment the following data were collected, Table 1. Calcium levels in the course of the control experiment are shown in Figure 3. 
Table 1. Physicochemical data collected during the "control" experiment.

\section{Control}

\begin{tabular}{cccccc}
\hline $\begin{array}{c}\text { Time } \\
(\mathbf{h})\end{array}$ & $\begin{array}{c}\text { Basin } \\
\text { temperature } \\
\left({ }^{\circ} \mathbf{C}\right)\end{array}$ & $\begin{array}{c}\text { Outlet } \\
\text { temperature } \\
\left({ }^{\circ} \mathbf{C}\right)\end{array}$ & $\begin{array}{c}\text { Inlet } \\
\text { temperature } \\
\left({ }^{\circ} \mathbf{C}\right)\end{array}$ & $\begin{array}{c}\text { Heat exchanger } \\
\text { temperature } \\
\left({ }^{\circ} \mathbf{C}\right)\end{array}$ & Ca level (ppm) \\
\hline 0 & 33.0 & 45.7 & 32.2 & 42 & 70 \\
\hline 0.5 & 35.7 & 48.8 & 34.4 & 43 & 79 \\
\hline 1.0 & 36.7 & 49.5 & 35.8 & 44 & 96 \\
\hline 2.0 & 37.7 & 50.1 & 36.7 & 44 & 100 \\
\hline 2.5 & 37.9 & 50.1 & 36.6 & 43 & 103 \\
\hline 3.5 & 37.7 & 50.0 & 36.4 & 43 & 107 \\
\hline 4.5 & 37.2 & 49.5 & 36.5 & 43 & 110 \\
\hline 5.5 & 36.8 & 49.4 & 36.3 & 43 & 104 \\
\hline 6.5 & 37.2 & 49.6 & 36.5 & 50 & 104 \\
\hline
\end{tabular}

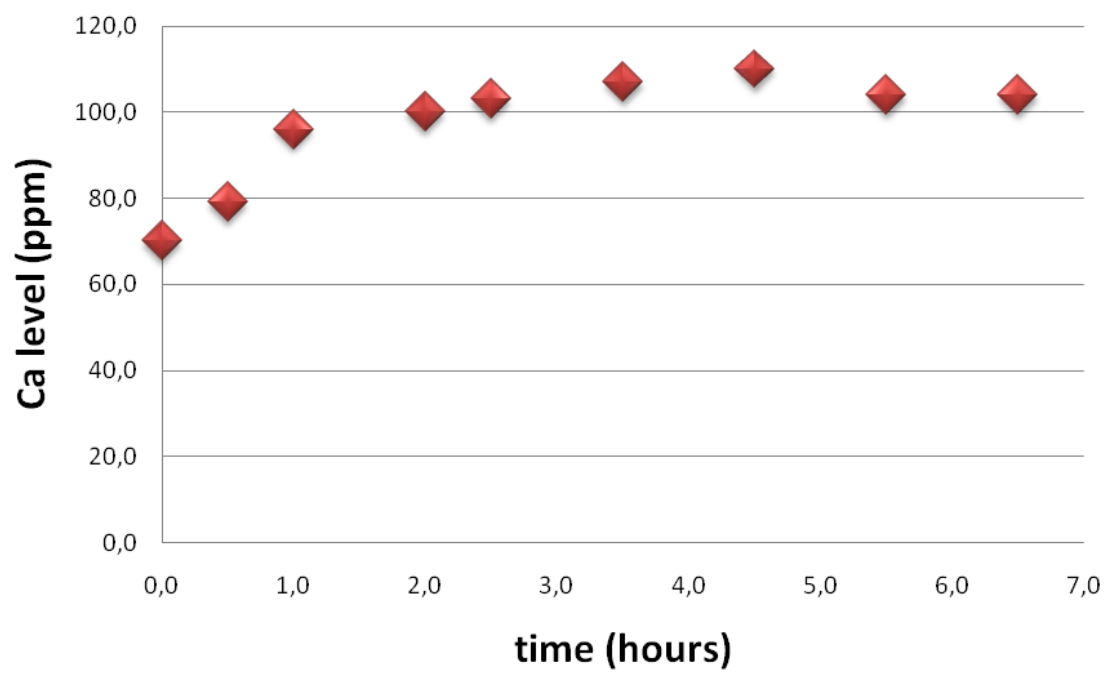

Figure 3. Calcium levels during the "control" experiment.

$\mathrm{Ca}$ levels rise for the first hour up to $\sim 100 \mathrm{ppm}$. This is expected because as water evaporates in the tower fill, the Ca concentration increases (together with all other soluble species). Increase of $\mathrm{Ca}$ levels flattens out after the third hour. In theory, they should continue increasing. This means that $\mathrm{Ca}$ is "lost" from solution because it forms $\mathrm{CaCO}_{3}$ onto the heat exchanger. This phenomenon is confirmed by visual inspection of the heat exchanger, where $\mathrm{CaCO}_{3}$ particle deposits are evident, Figure 4. 

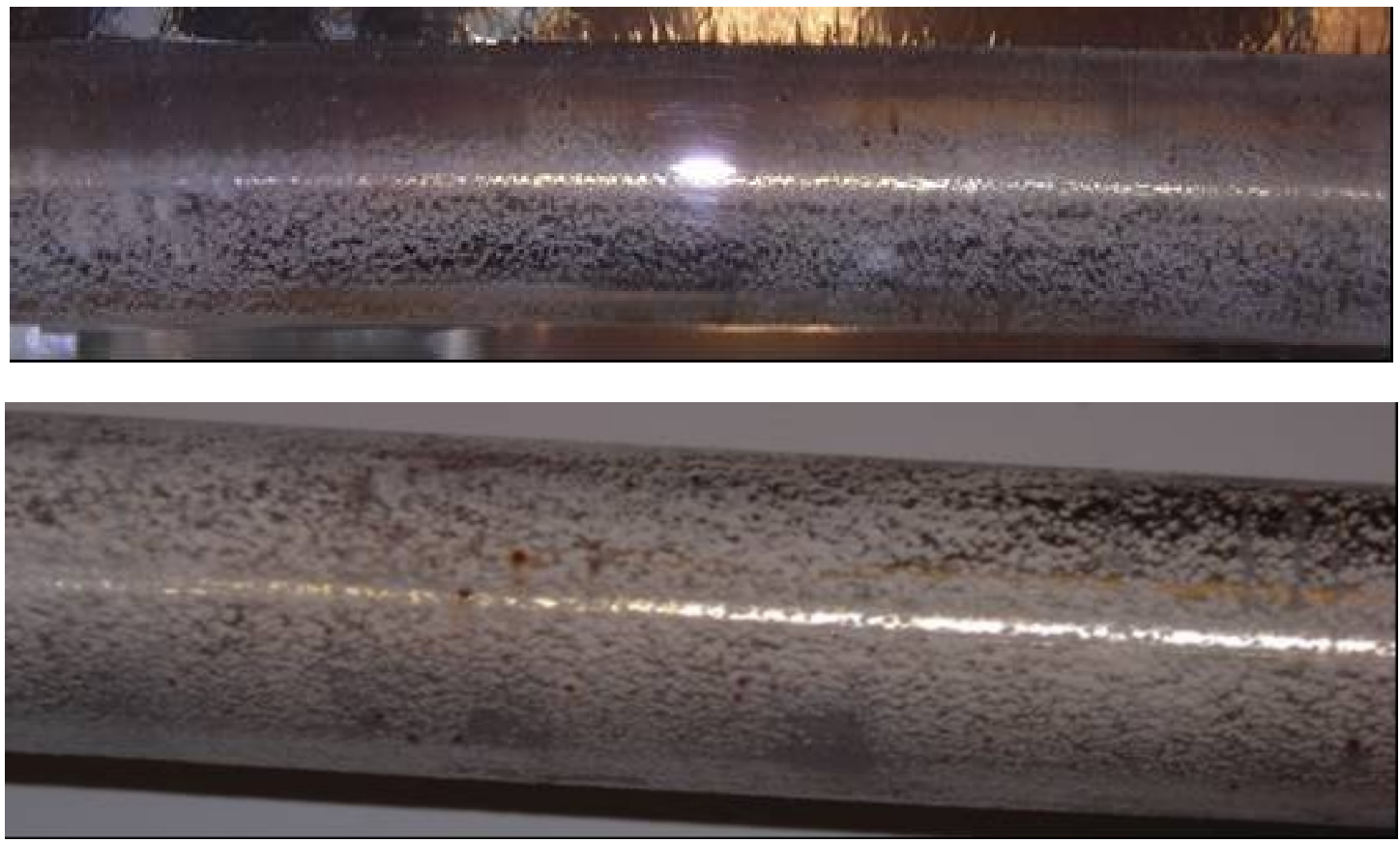

Figure 4. $\mathrm{CaCO}_{3}$ deposits on the heat exchanger in the control experiment.

\section{$\mathrm{CaCO}_{3}$ precipitation and deposition in the presence of PBTC (Dequest 7000)}

A second experiment was run identical to the control, however, $50 \mathrm{ppm}$ of PBTC (Dequest 7000) was added. Collected data are presented in Table 2. Ca levels during the course of the experiment are shown in Figure 5 and are compared to those of the "control".

Table 2. Physicochemical data collected during the experiment in the presence of PBTC (Dequest 7000).

\section{Dequest 7000 (PBTC)}

\begin{tabular}{cccccc}
\hline $\begin{array}{c}\text { Time } \\
(\mathbf{h})\end{array}$ & $\begin{array}{c}\text { Basin } \\
\text { temperature } \\
\left({ }^{\mathbf{O}} \mathbf{C}\right)\end{array}$ & $\begin{array}{c}\text { Outlet } \\
\text { temperature } \\
\left({ }^{\mathbf{O}} \mathbf{C}\right)\end{array}$ & $\begin{array}{c}\text { Inlet } \\
\text { temperature } \\
\left({ }^{\mathbf{O}} \mathbf{C}\right)\end{array}$ & $\begin{array}{c}\text { Heat exchanger } \\
\text { temperature } \\
\left({ }^{\mathbf{O}} \mathbf{C}\right)\end{array}$ & Ca level (ppm) \\
\hline 0 & 29.9 & 38.2 & 28.8 & 118 & 77 \\
\hline 0.5 & 31.8 & 35.7 & 30.9 & 72 & \\
\hline 1.25 & 32.2 & 40.1 & 31.3 & 97 & 80 \\
\hline 1.75 & 31.2 & 37.3 & 30.8 & 80 & \\
\hline 2.0 & 32.1 & 39.5 & 31.3 & 91 & 110 \\
\hline 2.75 & 31.8 & 39.8 & 31.2 & 91 & \\
\hline 3.25 & 32.0 & 40.1 & 31.3 & 86 & 130 \\
\hline 4.5 & 32.8 & 37.0 & 32.8 & 69 & \\
\hline 5.0 & 32.1 & 40.0 & 31.5 & 79 & \\
\hline 5.5 & 31.8 & 36.7 & 31.8 & 87 & \\
\hline
\end{tabular}




\begin{tabular}{l|l|l|l|l|l}
\hline 6.0 & 32.1 & 40.0 & 31.5 & 101 & 138 \\
6.5 & 32.0 & 40.1 & 31.5 & 110 & 110 \\
7.0 & 31.8 & 39.8 & 31.1 & 99 & 145 \\
7.5 & 31.1 & 38.6 & 30.5 & 87 & 159 \\
8.0 & 31.5 & 36.6 & 31.0 & & \\
\hline
\end{tabular}

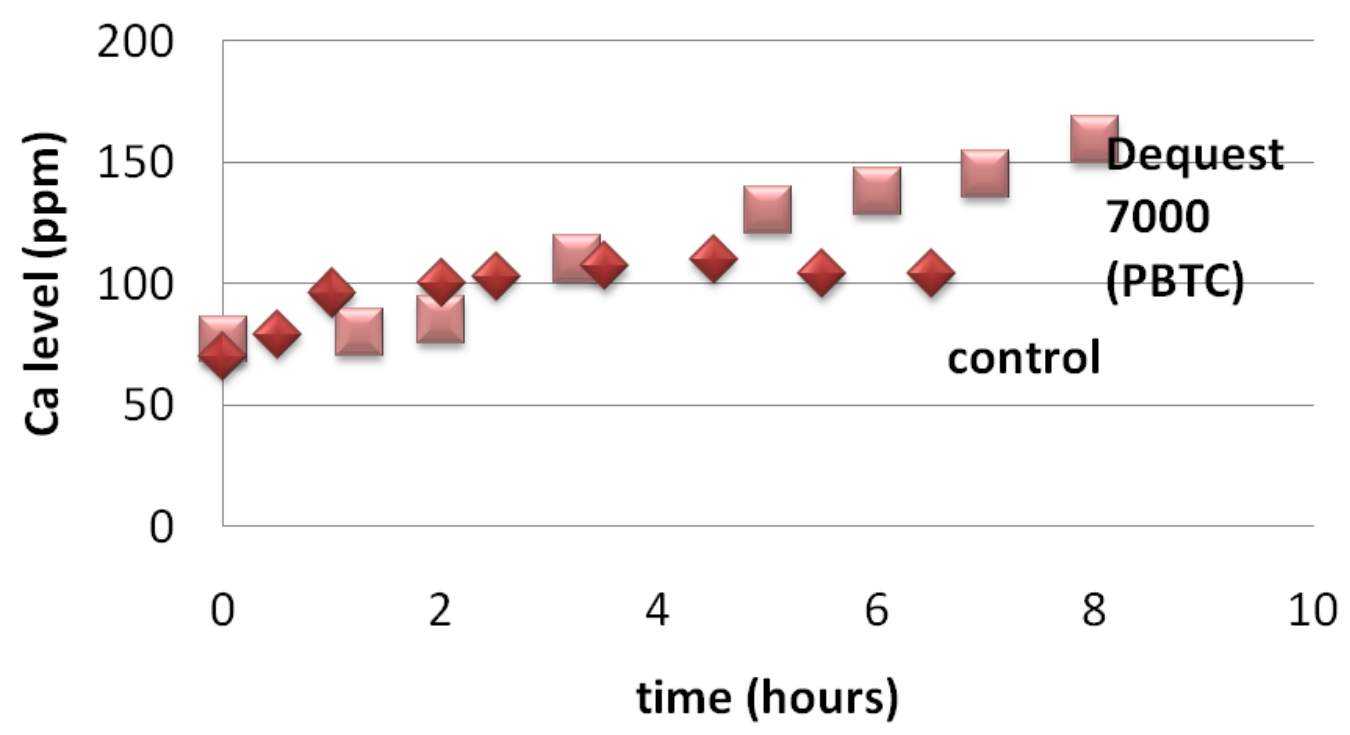

Figure 5. Calcium levels during the experiment in the presence of PBTC (Dequest 7000).

Here, we observe that the Ca levels do not level off, but continue to rise, an indication that there is no precipitation of $\mathrm{CaCO}_{3}$ on the heat exchanger. The experiment was stopped after 8 hours, with a final Ca level of $\sim 160 \mathrm{ppm}$, more than double the initial Ca level $(70 \mathrm{ppm})$. The heat exchanger was visually inspected, and no $\mathrm{CaCO}_{3}$ deposits were observed, Figure 6.
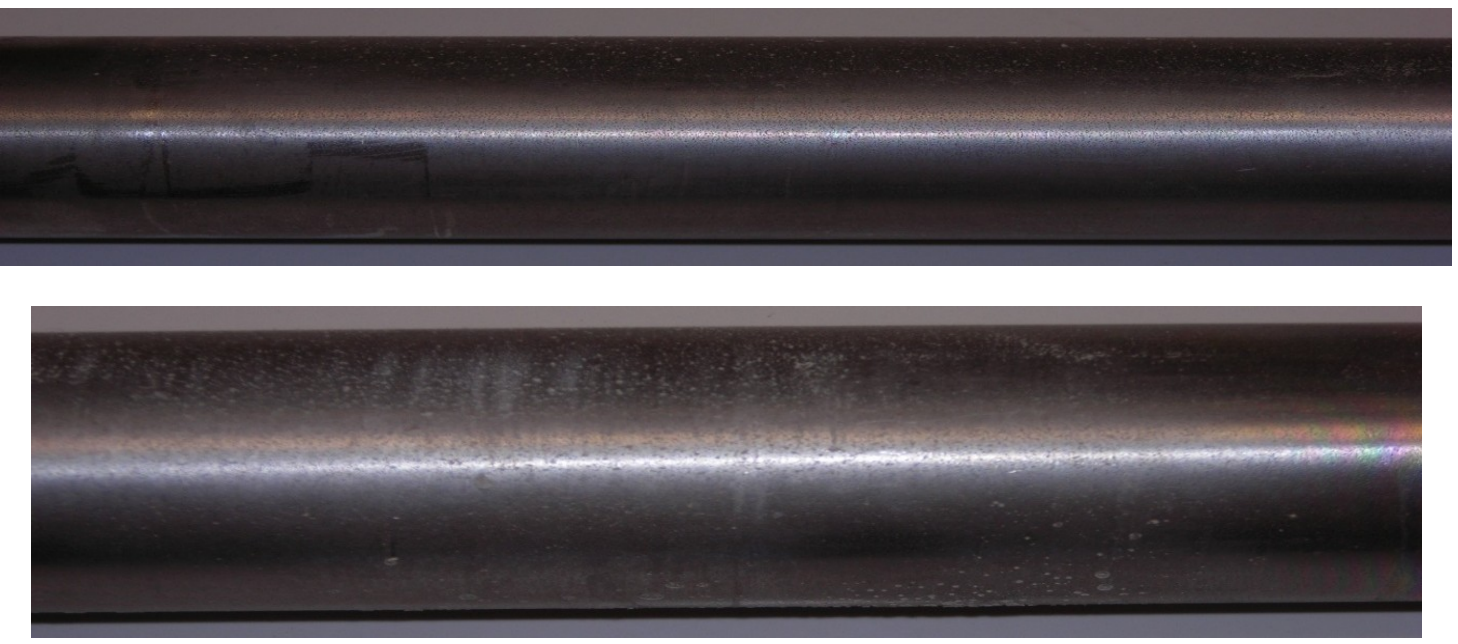

Figure 6. Absence of $\mathrm{CaCO}_{3}$ deposits on the heat exchanger in the experiment with PBTC (Dequest 7000) as inhibitor. 


\section{$\mathrm{CaCO}_{3}$ precipitation and deposition in the presence of BHPMP (Dequest 2090)}

A third experiment was run identical to the control, however, $50 \mathrm{ppm}$ of BHPMP (Dequest 2090) was added. Collected data are presented in Table 3. Ca levels during the course of the experiment are shown in Figure 7 and are compared to those of the "control".

Table 3. Physicochemical data collected during the experiment in the presence of BHPMP (Dequest 2090).

\section{BHPMP (Dequest 2090)}

\begin{tabular}{cccccc}
\hline $\begin{array}{c}\text { Time } \\
(\mathbf{h})\end{array}$ & $\begin{array}{c}\text { Basin } \\
\text { temperature } \\
\left({ }^{\circ} \mathbf{C}\right)\end{array}$ & $\begin{array}{c}\text { Outlet } \\
\text { temperature } \\
\left({ }^{\circ} \mathbf{C}\right)\end{array}$ & $\begin{array}{c}\text { Inlet } \\
\text { temperature } \\
\left({ }^{\circ} \mathbf{C}\right)\end{array}$ & $\begin{array}{c}\text { Heat exchanger } \\
\text { temperature } \\
\left({ }^{\circ} \mathbf{C}\right)\end{array}$ & Ca level (ppm) \\
\hline 0 & 26.2 & 35.0 & 26.1 & 97 & 69 \\
\hline 0.5 & 28.4 & 36.7 & 27.7 & 100 & 79 \\
\hline 1.00 & 27.3 & 36.5 & 27.0 & 103 & 90 \\
\hline 1.30 & 27.7 & 36.8 & 27.1 & 103 & 120 \\
\hline 2.0 & 27.7 & 36.0 & 26.9 & 101 & 129 \\
\hline 4.25 & 27.6 & 35.8 & 26.5 & 101 & 159 \\
\hline
\end{tabular}

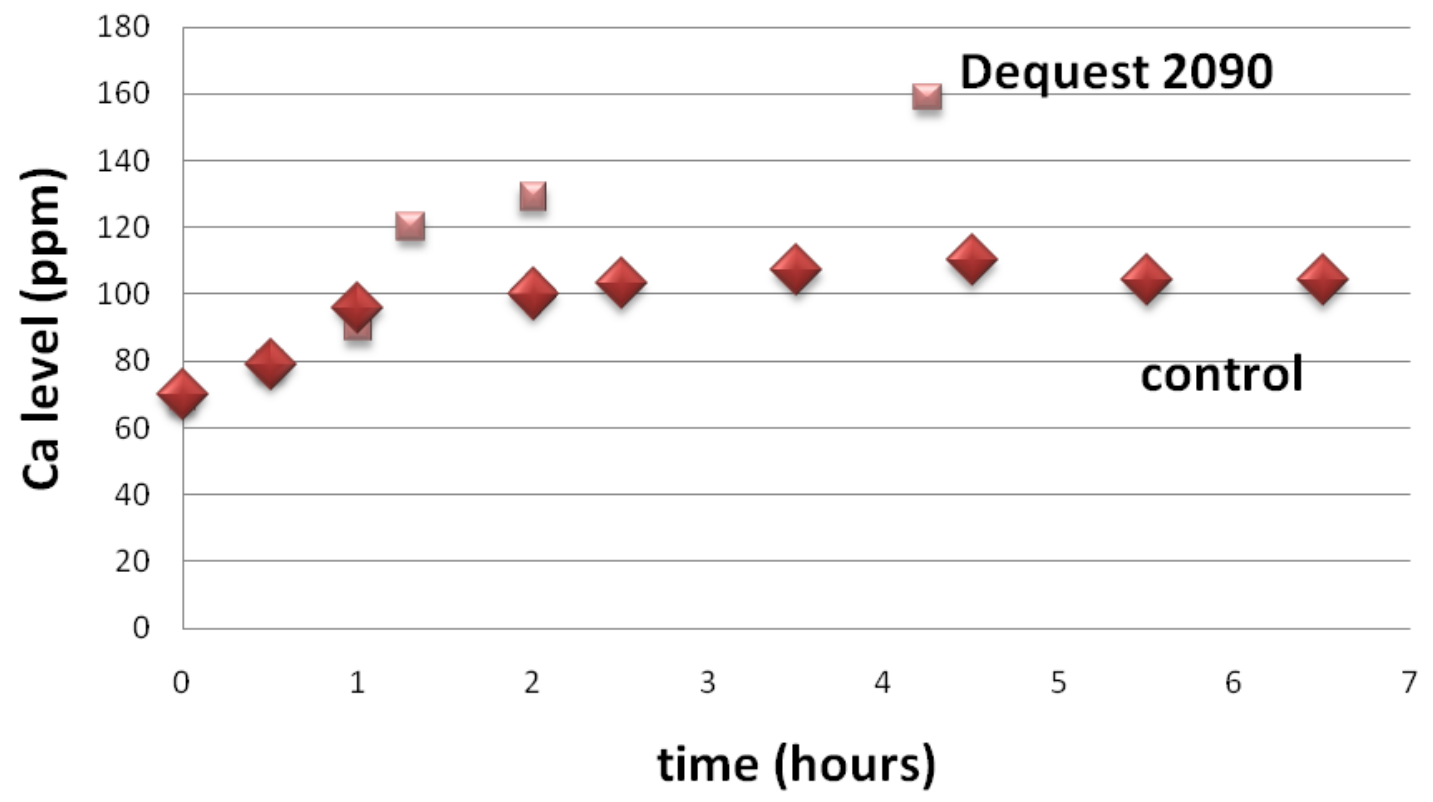

Figure 7. Calcium levels during the experiment in the presence of BHPMP (Dequest 2090).

Based on the results of Figure 7, we observe that the Ca levels do not level off, but continue to rise, an indication that there is no precipitation of $\mathrm{CaCO}_{3}$ on the heat exchanger. The experiment was stopped after 4.5 hours, with a final $\mathrm{Ca}$ level of $\sim 160 \mathrm{ppm}$, 
more than double the initial Ca level (70 ppm). The heat exchanger was visually inspected, and no $\mathrm{CaCO}_{3}$ deposits were observed, Figure 8.
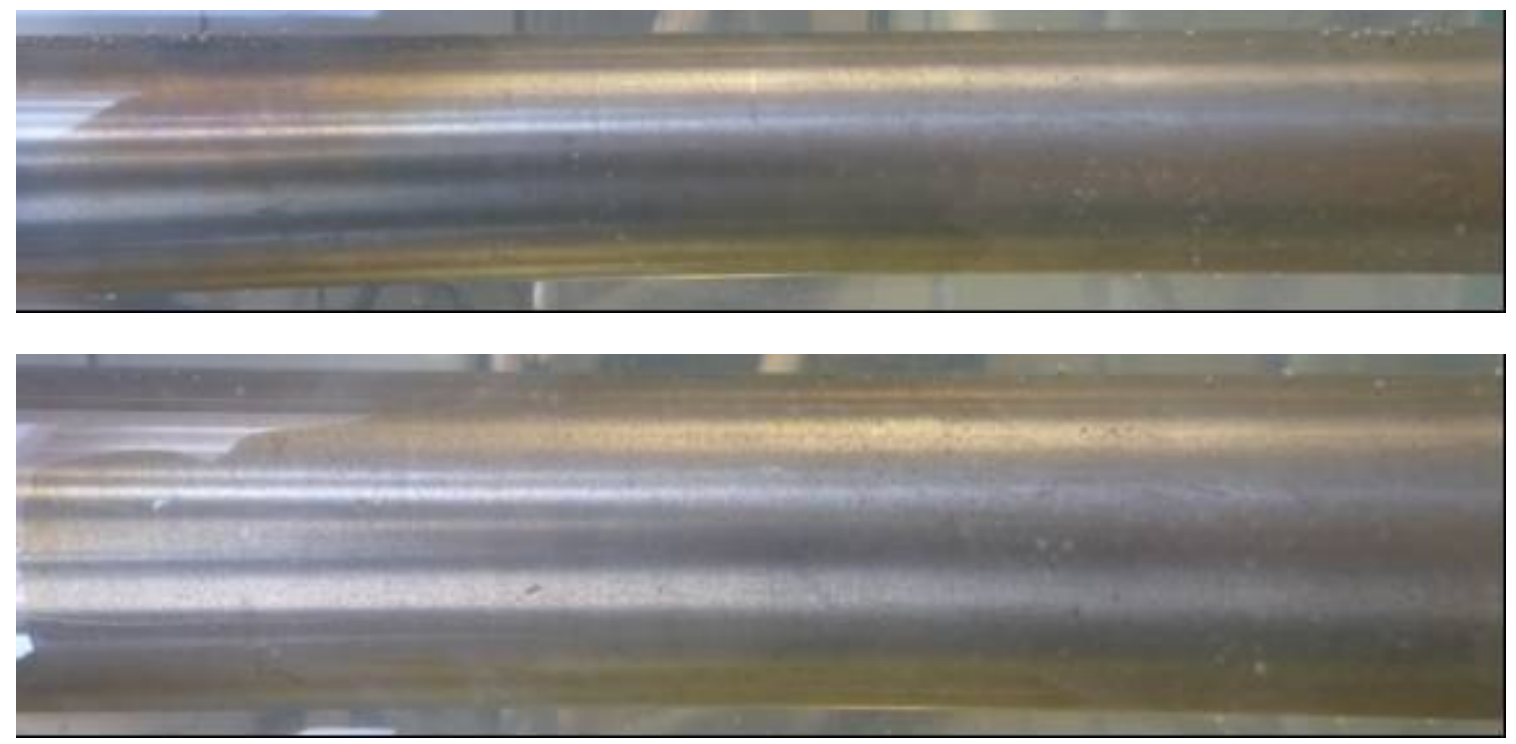

Figure 8. Absence of $\mathrm{CaCO}_{3}$ deposits on the heat exchanger in the experiment with BHPMP (Dequest 2090) as inhibitor.

\section{$\mathrm{CaCO}_{3}$ precipitation and deposition in the presence of $\mathrm{CMI}$ (Dequest $\left.\mathrm{PB}-11615\right)$}

A fourth experiment was run identical to the control, however, $50 \mathrm{ppm}$ of the polymeric inhibitor Dequest PB 11615 was added. Collected data are presented in Table 4. Ca levels during the course of the experiment are shown in Figure 9 and are compared to those of the "control".

Table 4. Physicochemical data collected during the experiment in the presence of Dequest PB 11615.

\begin{tabular}{cccccc}
\hline \multicolumn{5}{c}{ Dequest PB 11615 } \\
\hline $\begin{array}{c}\text { Time } \\
(\mathbf{h})\end{array}$ & $\begin{array}{c}\text { Basin } \\
\text { temperature } \\
\left({ }^{\circ} \mathbf{C}\right)\end{array}$ & $\begin{array}{c}\text { Outlet } \\
\text { temperature } \\
\left({ }^{\circ} \mathbf{C}\right)\end{array}$ & $\begin{array}{c}\text { Inlet } \\
\text { temperature } \\
\left({ }^{\circ} \mathbf{C}\right)\end{array}$ & $\begin{array}{c}\text { Heat exchanger } \\
\text { temperature } \\
\left({ }^{\circ} \mathbf{C}\right)\end{array}$ & Ca level (ppm) \\
\hline 0 & 35.3 & 47.2 & 33.1 & 54 & 72 \\
\hline 1.0 & 37.3 & 50.3 & 35.5 & 56 & 80 \\
\hline 3.0 & 35.5 & 50.3 & 35.5 & 54 & 98 \\
\hline 5.0 & 37.0 & 50.5 & 36.3 & 55 & 110 \\
\hline 6.0 & 35.2 & 50.5 & 34.6 & 55 & 118 \\
\hline 7.0 & 35.7 & 50.6 & 35.0 & 56 & 145 \\
\hline
\end{tabular}




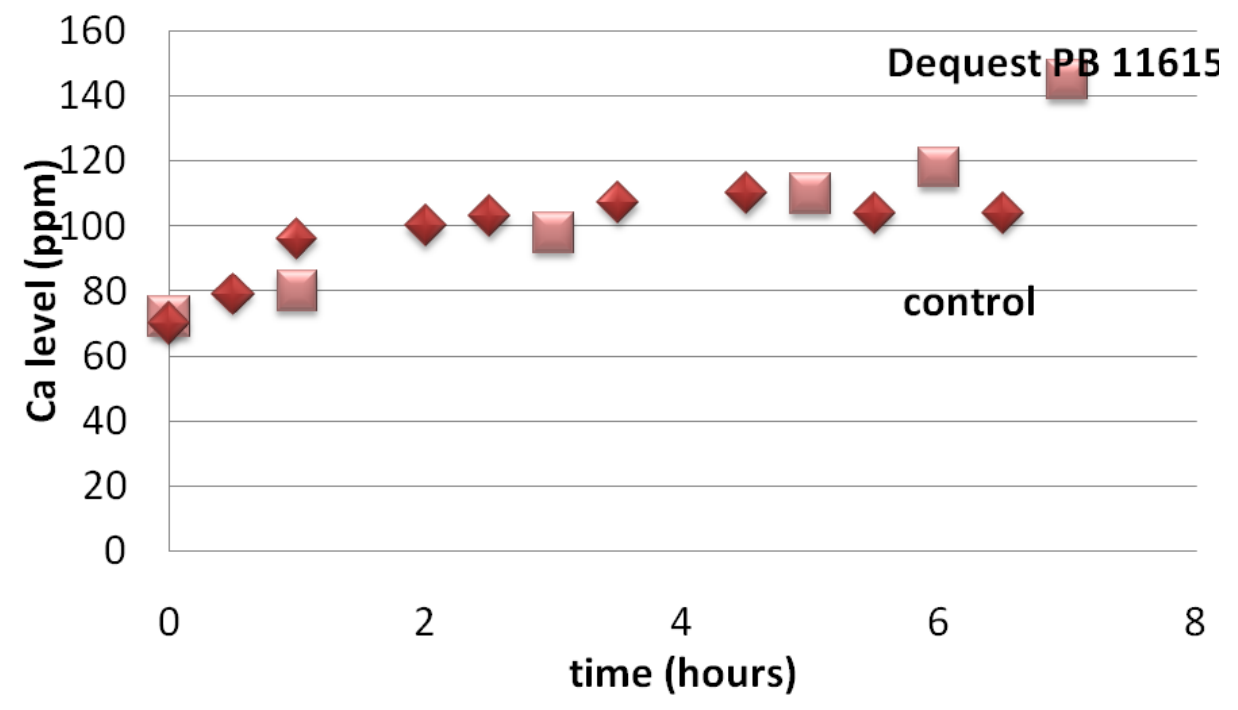

Figure 9. Calcium levels during the experiment in the presence of Dequest PB 11615.

It is observed that the Ca levels rise, but at a lower rate than that observed for the previous two inhibitors (PBTC and BHPMP). The trend continues to be upward, with a final Ca level of $145 \mathrm{ppm}$. Still, this Ca level is sufficiently higher than the control. We can therefore conclude that Dequest PB 11615 is a moderately effective inhibitor of $\mathrm{CaCO}_{3}$. Visual inspection of the heat exchanger reveals that it is mostly free of deposits, Figure 10.
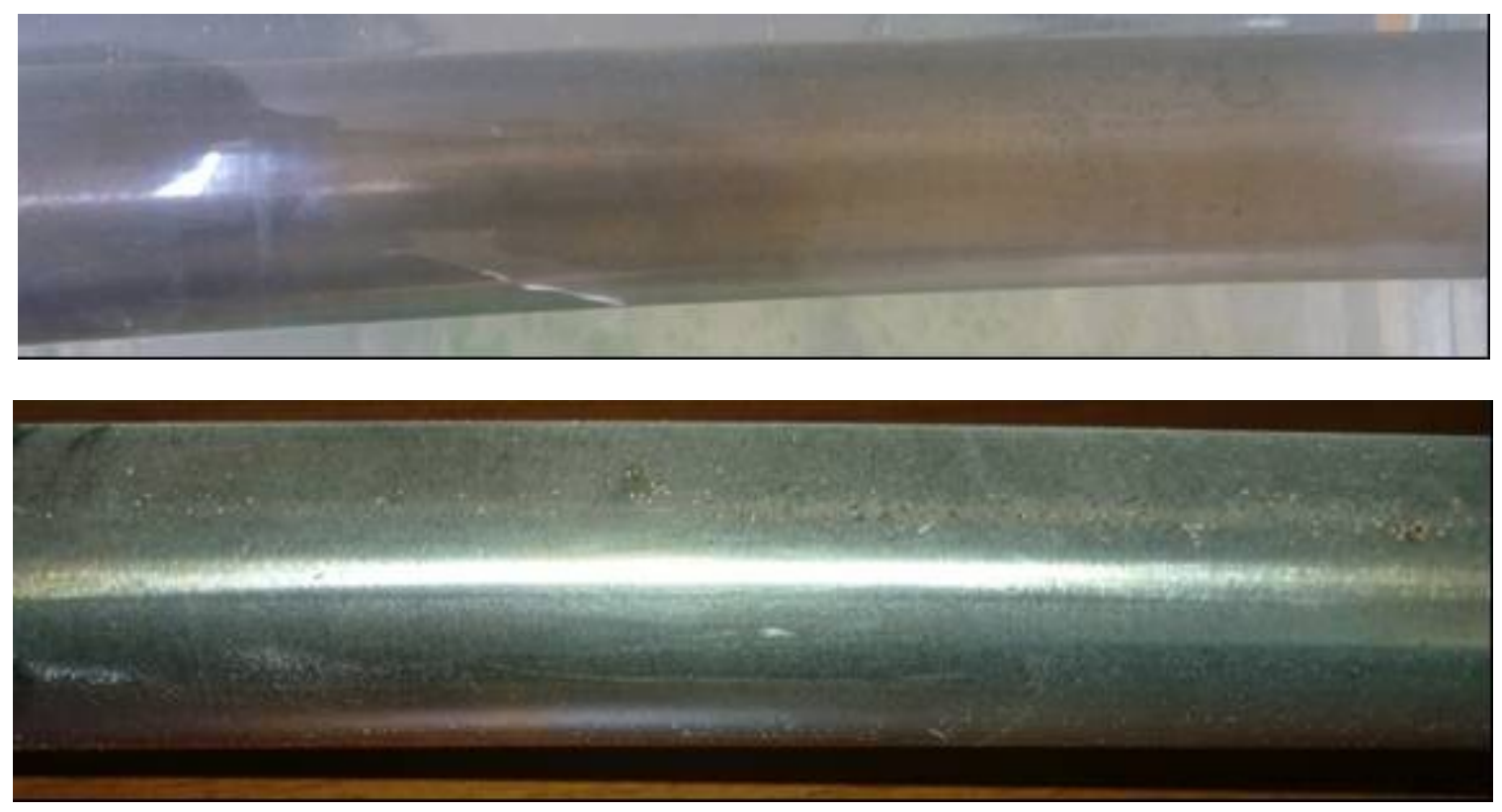

Figure 10. Absence of $\mathrm{CaCO}_{3}$ deposits on the heat exchanger in the experiment with Dequest PB 11615 as inhibitor.

\section{$\mathrm{CaCO}_{3}$ precipitation and deposition in the presence of $\mathrm{CMI}$ (Dequest $\mathrm{PB}-11620$ )}

A fifth experiment was run identical to the control, however, $50 \mathrm{ppm}$ of the polymeric inhibitor Dequest PB 11620 was added. Collected data are presented in Table 5. Ca levels 
during the course of the experiment are shown in Figure 11 and are compared to those of the "control".

Table 5. Physicochemical data collected during the experiment in the presence of Dequest PB 11620.

\section{Dequest PB 11620}

\begin{tabular}{cccccc}
\hline $\begin{array}{c}\text { Time } \\
(\mathbf{h})\end{array}$ & $\begin{array}{c}\text { Basin } \\
\text { temperature } \\
\left({ }^{\circ} \mathbf{C}\right)\end{array}$ & $\begin{array}{c}\text { Outlet } \\
\text { temperature } \\
\left({ }^{\circ} \mathbf{C}\right)\end{array}$ & $\begin{array}{c}\text { Inlet } \\
\text { temperature } \\
\left({ }^{\circ} \mathbf{C}\right)\end{array}$ & $\begin{array}{c}\text { Heat exchanger } \\
\text { temperature } \\
\left({ }^{\circ} \mathbf{C}\right)\end{array}$ & Ca level (ppm) \\
\hline 0 & 31.2 & 42.5 & 29.8 & 52 & 76 \\
\hline 1.0 & 37.7 & 49.7 & 36.1 & 56 & 89 \\
\hline 2.0 & 37.5 & 50.8 & 36.8 & 56 & 99 \\
\hline 3.0 & 37.9 & 50.6 & 36.3 & 56 & 120 \\
\hline 4.0 & 38.0 & 51.2 & 37.5 & 59 & 125 \\
\hline 5.5 & 35.6 & 51.5 & 38.0 & 55 & 135 \\
\hline
\end{tabular}

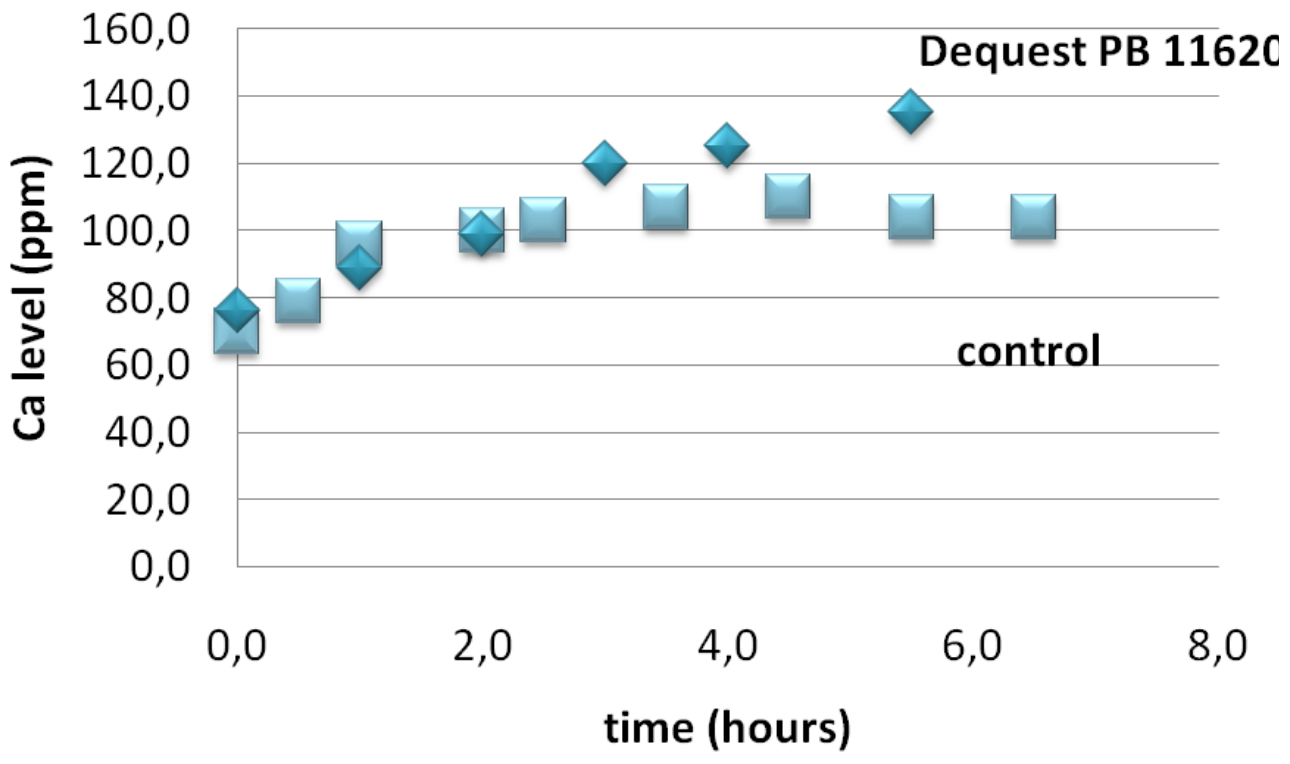

Figure 11. Calcium levels during the experiment in the presence of Dequest PB 11620.

Dequest PB 11620 shows a similar inhibition performance as Dequest PB 11615. The $\mathrm{Ca}$ levels rise, but at a lower rate than that observed for the two inhibitors PBTC and BHPMP. The trend continues to be upward, with a final Ca level of $135 \mathrm{ppm}$. Still, this Ca level is sufficiently higher than the control. We can therefore conclude that Dequest PB 11620 (like PB 11615) is a moderately effective inhibitor of $\mathrm{CaCO}_{3}$. Visual inspection of the heat exchanger reveals that it is mostly free of deposits, Figure 12. 

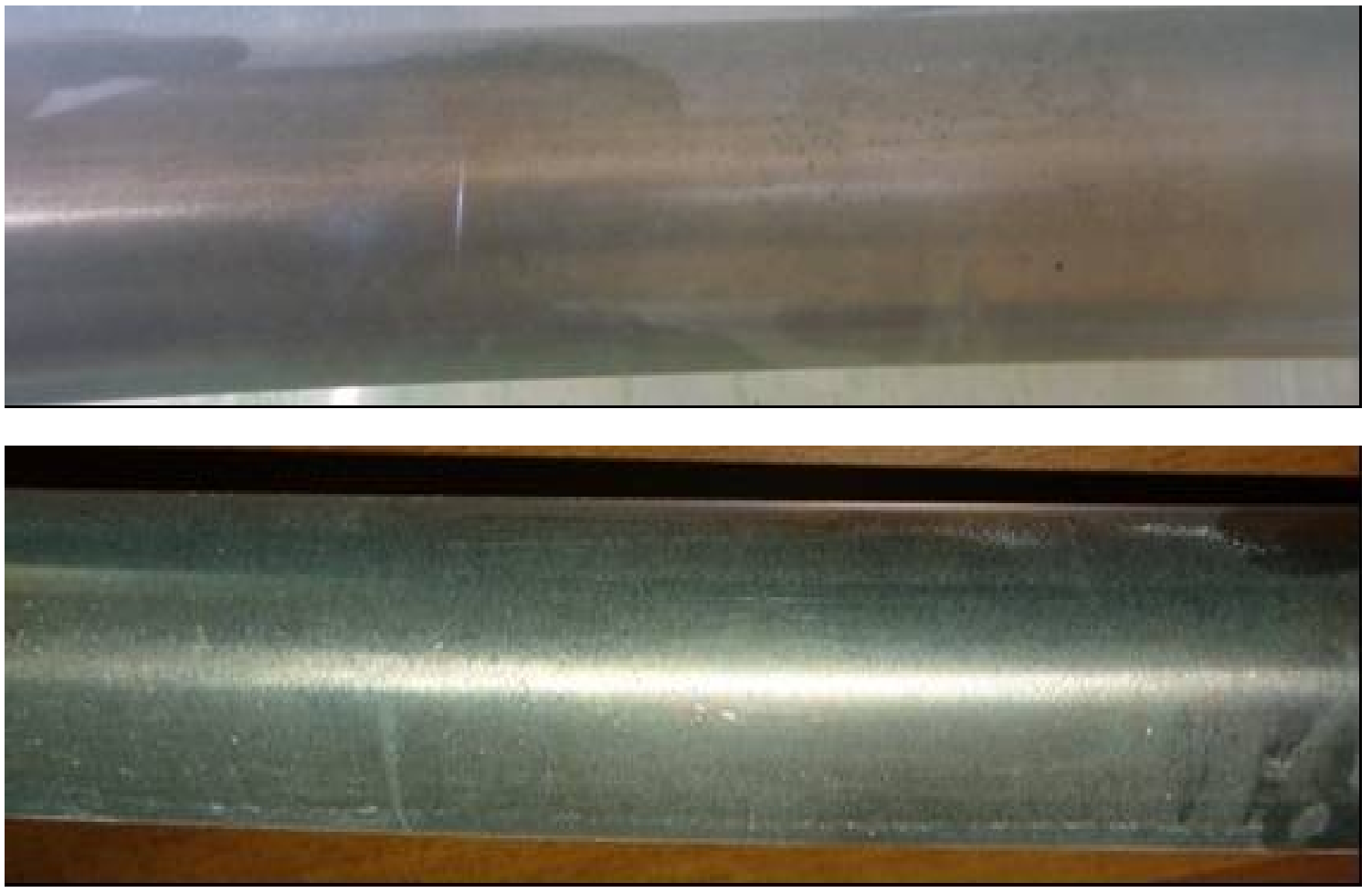

Figure 12. Absence of $\mathrm{CaCO}_{3}$ deposits on the heat exchanger in the experiment with Dequest PB 11620 as inhibitor.

\section{Conclusions}

In this paper we reported the use of a pilot heat exchanger-cooling tower prototype in evaluating $\mathrm{CaCO}_{3}$ scale inhibitors. The advantage of the utilization of such a system is that the scale inhibitors are tested under real dynamic conditions, taking into account physicochemical variables such as temperature, water flow, and the presence of a heated surface. Such studies offer a more realistic evaluation over bench-top tests, commonly encountered in the literature.

Figure 13 presents a comparison of all scale inhibitors studied so far. It appears that the ranking of inhibitor efficiency is:

$$
\mathrm{PBTC} \cong \mathrm{BHPMP}>\mathrm{PB}-11620>\text { PB-11615 }
$$

Although PBTC and BHPMP have dramatically different chemical structures (see Figure 2) they exhibit virtually identical inhibitory features. It is possible that the inhibition mechanisms are different for the two inhibitors, albeit yielding the same result. It is also interesting to note that the two "green" polymers of carboxymethyl inulin are acceptable scale inhibitors, with PB-11620 being slightly more effective than PB-11615. This is justified by the higher carboxymethylation degree of PB-11620 compared to that of PB11615.

Research on scale inhibitors is still active. The current trend is the discovery/design of new inhibitor structures that are both effective and environmentally-friendly. Our group has contributed a number of papers to that effect [16-21]. 


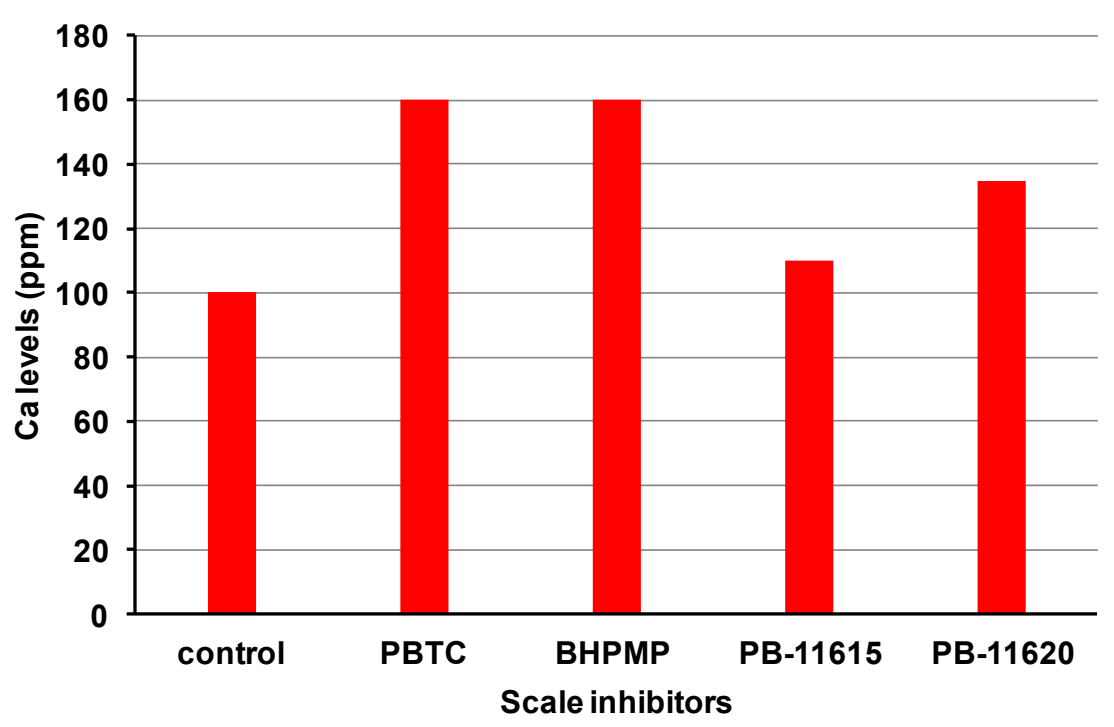

Figure 13. Comparison of scale inhibitor efficiencies of PBTC, BHPMP, PB-11615, and PB11620.

\section{References}

1. J. C. Cowan and D. J. Weintritt, Water-Formed Scale Deposits, Gulf Publishing Co., Houston, TX, 1976.

2. T. R. Bott, Fouling of Heat Exchangers, Elsevier Science, 1995.

3. K. D. Demadis, in Compact Heat Exchangers and Enhancement Technology for the Process Industries, R. K. Shah, Editor, Begell House Inc., 2003, pp. 483-490.

4. Z. Amjad, Mineral Scale Formation and Inhibition, Plenum Press, New York, 1995.

5. K. D. Demadis, M. Somara and E. Mavredaki, Ind. Eng. Chem. Res., 2012, 51, 2952.

6. K. D. Demadis and S. D. Katarachia, Phosphorus Sulfur Silicon, 2004, 179, 627.

7. E. Akyol, M. Öner, E. Barouda and K. D. Demadis, Cryst. Growth Des., 2009, 9, 5145.

8. B. Akın, M. Öner, Y. Bayram and K. D. Demadis, Cryst. Growth Des. 2008, 8, 1997.

9. E. Mavredaki, E. Neofotistou and K. D. Demadis, Ind. Eng. Chem. Res., 2005, 44, 7019.

10. D. L. Verraest, J. A. Peters, J. G. Batelaan and H. van Bekkum, Carbohydrate Res., 1995, 271, 101.

11. C. V. Stevens, A. Meriggi and K. Booten, Biomacromolecules, 2001, $2,1$.

12. F. R. Johannsen, Food Chem. Toxicol., 2003, 41, 49.

13. Data was kindly provided by Solutia Inc.

14. S. Mishra and A.D. Patil, Chem. Eng. Technol., 2002, 25, 573.

15. E. Antonogiannakis, E. Tzagkaraki and K. D. Demadis, Int. J. Corros. Scale Inhib., 2013, 2, no. 3, 216. doi10.17675/2305-6894-2013-2-3-216-223

16. K. D. Demadis, E. Barouda, N. Stavgianoudaki and H. Zhao, Cryst. Growth Des., 2009, 9, 1250.

17. K. D. Demadis, A. Ketsetzi, K. Pachis and V. M. Ramos, Biomacromolecules, 2008, 9, 3288. 
18. A. N. Kofina, K. D. Demadis and P. G. Koutsoukos, Cryst. Growth Des., 2007, 7, 2705.

19. E. Barouda, K. D. Demadis, S. Freeman, F. Jones and M. I. Ogden, Cryst. Growth Des., 2007, 7, 321.

20. E. Mavredaki, E. Neofotistou and K. D. Demadis, Ind. Eng. Chem. Res., 2005, 44, 7019.

21. A. Stathoulopoulou and K. D. Demadis, Desalination, 2008, 224, 223. 